\title{
De Dom Casmurro a Capitu: problemas de um percurso transtextual
}

\section{João Manuel dos Santos Cunha*}

\begin{abstract}
Resumo: O ensaio investiga a tradução fílmica Capitu Abstract: This essay analyzes the filmic translation (Paulo Cezar Saraceni, 1968) para o romance Dom entitled Capitu (SARACENI, 1968) from the novel Casmurro (Machado de Assis, 1899), intermediando a Don Casmurro [Dom Casmurro] (ASSIS, 1899), as análise com o roteiro cinematográfico Capitu (Paulo well as its screenplay (GOMES; TELLES, [1967] Emilio Salles Gomes, Lygia Fagundes Telles, [1967] 1993), raising the question of range and efficacy of the 1993), com o intuito de problematizar o alcance e a transtextual operation attempted by the translators eficácia da operação transtextual intentada pelos concerning the status of the narrator, both in literary tradutores quanto ao estatuto do narrador em textos de and cinematographic texts.

ficção literária e cinematográfica.
\end{abstract}

Palavras-chave: Literatura Comparada; literatura e cinema; narrador.
Keywords: Comparative Literature; literature and cinema; narrator.

O cinema, desde os primeiros tempos do estabelecimento de sua linguagem narrativa, nas primeiras décadas do século XX, tem se valido de material literário para contar histórias. Pouco importa que sejam obras inéditas e inovadoras, textos consagrados pela tradição ou de sucesso popular; da mesma forma como não se considera o nível estético e o estatuto dessa literatura. Constata-se, entretanto, que tal estratégia retoma e persegue prática já costumeira no âmbito das adaptações teatrais. Foi de forma natural, então, que o termo "adaptação" começou a ser usado, tanto por profissionais da indústria cinematográfica como pela crítica, no caso da transposição do meio literário para o fílmico.

No quadro da investigação acadêmica sobre as relações entre literatura e cinema, vertente fértil vem se fortalecendo nos últimos tempos: a que se ocupa em refletir sobre a operação tradutora de textos literários para textos fílmicos. Ou seja, que analisa as denominadas "adaptações" cinematográficas. Acolhida naturalmente no campo dos estudos

\footnotetext{
* Doutor em Letras - Literatura Comparada (UFRGS, 1996); Pós-Doutor em Literatura e Cinema - (Sorbonne Nouvelle - Paris III, 1999). Professor de Literatura Brasileira; Literatura Comparada; Teoria e crítica literária, em Graduação e Pós-Graduação em Letras, lotado no Departamento de Letras Vernáculas da Faculdade de Letras, Universidade Federal de Pelotas. Email: profjoaomanuel@terra.com.br.
} 
sobre intertextualidade, essa prática vem construindo com eficácia instrumental metodológico compatível com o estatuto do comparatismo literário na contemporaneidade.

Por outro lado, a localização do problema no âmbito da Literatura Comparada proporcionou avanços inegáveis para a reflexão sobre o estatuto do narrador fílmico, enfocado agora em sua relação provisória com o narrador literário. Na operação tradutora do livro ao filme, entretanto, um aspecto crucial deve ser considerado: antes de a palavra escrita ser traduzida em imagem em movimento, é preciso que seja criado um estágio intermediário, um lugar de passagem do verbal para o imagético. Essa é a função do roteiro escrito, instrumento o qual, originado no literário, constitui-se em texto técnico que descreve o que deve ser posto em imagens fílmicas. Fixado no limbo espacial de não ser mais literatura e ainda não ser cinema, o roteiro pode ser peça fundamental para o entendimento de como se dá a especial tradução de um sistema de signos a outro.

Em 1993, vem à luz texto importante na constituição de um corpus analítico para a reflexão sobre as relações entre literatura e cinema, centradas no tema das traduções intersemióticas. Sai em livro o roteiro adaptado: Capitu - adaptação livre para um roteiro baseado no romance Dom Casmurro. Como paratexto, a obra inclui considerações de um dos autores - Lygia Fagundes Telles - sobre as condições em que os roteiristas se desincumbiram da tarefa. Isso é, o crítico e professor de cinema Paulo Emilio Salles Gomes e a própria escritora, instigados pelo cineasta Paulo Cezar Saraceni, que se apropriam do hipotexto literário de Machado de Assis e traduzem-no em outro objeto, o intertexto sob a forma técnica de roteiro escrito: Capitu. Narrativas em trânsito intertextual - romance, roteiro e filme ligam-se em rede transtextual, portanto. Rentável circunstância para uma reflexão no campo dos estudos de intertextualidade, na direção do que propôs Gérard Genette em sua teoria da transtextualidade ${ }^{1}$.

\footnotetext{
${ }^{1}$ Uso, como suporte teórico para as reflexões desenvolvidas neste texto, as categorias da teoria da transtextualidade proposta por Gérard Genette (1982, p.8-12: intertextualidade, paratextualidade, metatextualidade, arquitextualidade e hipertextualidade. A da intertextualidade é vista como uma relação de copresença entre dois ou mais textos, ou seja, como a presença efetiva de um texto em outro. Com a da paratextualidade, ele identifica as relações entre o texto literário propriamente dito e outros textos - paratextos que o cercam, constituindo, com ele, o conjunto textual; incluem-se aí elementos como título, subtítulo, prefácio, posfácio, notas marginais ("explicativas", "do tradutor"), epígrafes, ilustrações, notas de rodapé, "advertências do editor", premissas, e até metatextos formalizados como apresentação de leitura crítica sobre o hipotexto, metalingüísticos ou translingüísticos, veiculados na própria capa ou em contracapa e orelhas do livro, por exemplo. Apresentada como a relação crítica paradigmática entre textos literários, a categoria da metatextualidade dá conta de textos que falam sobre outros textos, em forma de comentário crítico, ainda que não haja citação explicitada. A da arquitextualidade implica a suposição de analogias formais ou de conteúdo entre textualidades, ou dessas com discursos diversos, considerando que há elementos comuns entre eles que os circunscrevem, por exemplo, a um gênero ou movimento. Finalmente, ao propor a modalidade de hipertextualidade, ele supõe a existência de um texto preexistente - hipotexto - em função do qual outro se
} 
Espaço ideal, dessa forma, para a verificação de como se dá a produção de sentido no entrecruzamento de códigos diversos, a tradução fílmica pode ser entendida como foco significante que ilumina seu hipotexto. Quando se analisa esses fatos, é preciso considerar como fundamental o pressuposto de que, se houve tradução, houve antes interpretação. Ao reescreverem Dom Casmurro, os específicos leitores/tradutores o que fizeram foi primeiro interpretar o texto machadiano. O filme - tanto como o roteiro escrito, obra independente em sua individualidade estética - é leitura do romance, ressalvadas as especificidades dos textos literário e fílmico: obras distintas em suas características formais - uma, o livro, narrativa literária; outra, o filme, narrativa fílmica ${ }^{2}$.

Não se pretende, neste ensaio, repassar o que já foi tratado nesses mais de cem anos de permanência do "enigma de Capitu" na agenda da crítica literária. O objetivo é o de tratar a questão a partir do fato de existir uma reescrita do texto machadiano que se destina a uma empreitada muito especial: a da tradução do texto verbal em filme para cinema, mediada pela existência de um roteiro escrito. Ou seja, a tradução de um texto literário para um texto fílmico ${ }^{3}$ - Dom Casmurro (1899) e Capitu $^{4}$ (1968) - por meio de um texto paraliterário - o roteiro Capitu (1967).

A operação intersemiótica ${ }^{5}$ de levar para a tela de cinema uma narrativa literária prevê, antes de tudo, a existência de um roteiro escrito - texto técnico essencial para a filmagem da história e que, dadas as suas características formais (possibilidade de circular sob a forma de

estrutura - o hipertexto, ou "texto de segundo grau", já que se constitui a partir de um "texto primeiro". Ou, simplesmente, "toda relação que une um texto (texto B - hipertexto) a outro texto (texto A - hipotexto).

2 É consenso entre a crítica, hoje, que o "texto fílmico" tem autonomia de código narrativo. Cf. METZ, Christian. A significação no cinema. São Paulo: Perspectiva, 1972, p.338: "O cinema não é uma língua, sem dúvida nenhuma, mas pode ser considerado como uma linguagem, na medida em que ordena elementos significativos no seio de combinações reguladas, diferentes daquelas praticadas pelos idiomas e que tampouco decalcam a realidade. Assim, sendo uma linguagem, permite uma escrita, isto é, o texto fílmico".

${ }^{3}$ A noção de texto fílmico, eminentemente complexa, pode ser entendida como "uma rede de significações múltiplas”, cf. MIMOSO-RUIZ, Duarte. Narração fílmica e narração literária: perspectivas semiológicas. Anais do $1^{\circ}$ Congresso da ABRALIC, Porto Alegre, p.235, 1989. Ou, cf. METZ, op.cit., p.338: “O resultado provisoriamente parado do trabalho com códigos: isto é, o filme".

${ }^{4}$ Saraceni, Paulo Cezar. Capitu. Rio de Janeiro, Sant'anna Produtora Brasileira de Filmes, 1968. Warner Home Video Brazil, 1989: versão em VHS/NSTC, preto e branco, 103'. Roteiro de Lygia Fagundes Telles, Paulo Emilio Salles Gomes e Paulo Cezar Saraceni. Produção de Sérgio Saraceni. Intérpretes: Othon Bastos (Bentinho), Isabella (Capitu), Raul Cortez (Escobar).

5 "Tradução intersemiótica" é, cf. Plaza, "aquele tipo de tradução que consiste na interpretação dos signos verbais por meio de signos não-verbais; ou de um sistema de signos para outro, por exemplo, da arte verbal (literatura) para [...] o cinema" (PLAZA, Julio. Tradução intersemiótica. São Paulo: Perspectiva, 1987, p.XI). O conceito deriva, de qualquer forma, de Roman Jakobson e, segundo Plaza, o fenômeno pode ser designado também por "tradução criativa", ou "transcriação": ou seja, agora ampliando proposta de Haroldo de Campos: "a criação transitando de texto a texto pela tradução intersemiótica" (Cf. CAMPOS, Haroldo de. A arte no horizonte do provável. São Paulo: Perspectiva, 1969). 
livro, ser lido como literatura narrativa, independentemente do filme), pode até ser considerado por muitos como um novo "gênero" literário, com o mesmo status do texto cênico que constitui o "gênero dramático". O roteiro de Capitu, entretanto, é consequiência de intenção específica: traduzir um texto literário para o cinema por encomenda de um cineasta que intenta deslocar o eixo temático do romance, centrando a história na personagem feminina e que se configuraria na "adaptação cinematográfica"6 realizada por Lygia e Paulo Emilio. O fato cresce de interesse porque não são técnicos especializados da área do cinema aqueles que se desincumbiram da tradução do texto literário para roteiro a ser filmado.

Paulo Emilio Salles Gomes foi um dos intelectuais mais respeitados da cultura brasileira do século passado, quer como crítico de cinema e animador cultural, fundador da Cinemateca Brasileira. Um dos mais radicais defensores do cinema brasileiro, quer como ensaísta, professor e pesquisador de cinema, Salles Gomes é autor de um trabalho pioneiro, editado na França sobre o cineasta Jean Vigo, considerado hoje um dos textos fundadores da moderna crítica cinematográfica mundial. Seu ensaio Cinema: trajetória do subdesenvolvimento é uma das mais lúcidas reflexões sobre a situação do cinema no Brasil. Com centenas de críticas de cinema e artigos sobre cultura brasileira para jornais e revistas no Brasil e no exterior, Paulo Emilio também criou textos de ficção: seu Três Mulheres de três PPPês (GOMES, 1977) reúne três contos longos - "PI: duas vezes com Helena"; "PII Ermengarda com H"; "PIII: duas vezes com ela".

Lygia Fagundes Telles, companheira de Paulo Emilio até a morte dele, em 1977, também interessada em cinema, foi incentivadora e dirigente da Cinemateca Brasileira, de seus textos de ficção, pode-se dizer que alcançaram repercussão entre o público leitor e na crítica em nosso país. Embora não possa ser considerada como participante do que hoje se considera "literatura feminina", a maior parte de seus escritos tem como tema a mulher e a sua condição na sociedade brasileira, principalmente em As Meninas e As Horas Nuas. Notadamente a partir de As Meninas parte da crítica vem encontrando em sua arquitetura ficcional importante repercussão dos procedimentos narrativos do cinema.

É a esses dois roteiristas improvisados que o cineasta Paulo Cezar Saraceni encomenda a "adaptação" do livro de Machado de Assis para o cinema. A reunião dessas três pessoas envolvidas com a criação artística - quer no campo da produção de narrativas literárias e fílmicas, quer no da reflexão sobre o produto cultural e artístico, livro e filme, vai estabelecer uma especial circunstância na tradução do texto literário Dom Casmurro para o

\footnotetext{
${ }^{6}$ Cf. ficha técnica (“créditos”) do próprio filme.
} 
fílmico Capitu. Não se trata apenas de um trabalho técnico - é preciso reafirmar que Paulo Emilio e Lygia não eram roteiristas de cinema - mas de uma tradução para um outro código narrativo de uma obra de ficção literária por dois intelectuais que atuavam tanto no campo da criação literária como no da reflexão sobre a criação cinematográfica. Reunidos a um autor de cinema que já vinha cortejando o texto literário brasileiro desde Porto das Caixas (1962), filme realizado a partir de argumento do escritor Lucio Cardoso, de quem mais tarde filmaria Crônica da casa assassinada (A casa assassinada, 1970). Nessa rede de afinidades líterofílmicas verifica-se ainda que a aproximação do cineasta Saraceni com a literatura e com seu colaborador em Capitu, Paulo Emilio, vai levá-lo a filmar, em 1981, o conto "PI: duas vezes com Helena”, extraído do livro Três Mulheres de três PPPês (Ao sul do meu corpo). Fato a notar, também, é o de que, quando do lançamento de Porto das caixas, Paulo Emilio manifestou-se muito entusiasmado com o filme e escreveu literalmente o que se segue sobre a personagem feminina principal do filme: "Aquela Bovary que o contexto de subdesenvolvimento torna feroz, aquela fascinante e atroz Capitu suburbana, é o primeiro grande personagem feminino nascido no cinema brasileiro" (GOMES, 1981, p.410). O que pode colocar uma questão importante para a aproximação da reescrita de Dom Casmurro, o filme Capitu, como veremos na seqüência.

Produção de 1967, Capitu estreou em julho de 1968. Cinco anos após o aparecimento de Vidas secas (Nelson Pereira dos Santos, 1963) e de Deus e o diabo na terra do sol (Glauber Rocha, 1963), considerados hoje como os marcos fundamentais do chamado "Cinema novo" brasileiro. Paulo Cezar Saraceni, o diretor, foi um dos cineastas que iniciou esse movimento renovador da estética cinematográfica, em 1962, depois de retornar da Itália, onde foi roteirista de Marco Bellochio - L'alba romana, 1961 - e aluno do Centro Experimental de Cinema de Roma. Capitu, para Saraceni, "é um filme sobre a cultura brasileira, na sua linha feminista; de meus filmes, o mais cinematográfico; tinha felicidade de dirigir os atores, mexer a câmera" (MIRANDA, 1990, p.308-309). A crítica da época não recebeu bem o filme e nem o público o prestigiou. Para o crítico cinematográfico Cláudio Mello e Souza, por exemplo, o filme "não é nem uma recriação eficaz do romance, nem uma obra em si mesma: ao mesmo tempo em que Saraceni procura libertar-se do romance, permanece escravizado pelo universo verbal de Machado" (MELLO E SOUZA, 1968, p.4).

Depois de escapar de seu contexto literário e se transformar em personagem cinematográfica, Capitu retorna ao livro, com a publicação da "adaptação livre" para um roteiro baseado no romance. Vinte e seis anos depois de escrito, o texto de Lygia e Paulo Emilio parece confirmar o que em 1968 já era bastante visível no filme: que a leitura dos 
roteiristas investe em "esclarecer os fatos", limpando, por assim dizer, o texto original de seu necessário caráter ambíguo e paradoxal, postulando uma questão no mínimo instigante: ao mesmo tempo em que os tradutores atualizam a discussão da obra de Machado, colocam em tese a questão da tradução intersemiótica do livro ao filme. E mais: recolocam em cena, de forma problemática, um tema ainda não suficientemente desenvolvido em nosso meio, o do estatuto do narrador fílmico.

Ao propor a fatura do roteiro a Paulo Emilio e Lygia, Saraceni achou "complicado convencê-los de que o filme era sobre Capitu e não Dom Casmurro"7. A idéia que preside o projeto é, desde o início, então, a de recriar o texto machadiano, deslocando o foco narrativo de Bentinho para Capitolina: o que a troca de título da obra, de Dom Casmurro para Capitu só vem confirmar. Poder-se-ia pensar, então, apenas a partir desses dados, que vai se tratar da história literária recriada a partir do ponto de vista de um outro narrador (nesse caso, Capitu); ou, ainda, de que a narrativa quer é narrar "o outro lado da história".

Poder-se-ia entender, então, que, abordando dessa forma o texto de Machado, os roteiristas teriam privilegiado a narrativa em terceira pessoa, eis que, no romance, a personagem de Dom Casmurro-Bentinho - narrador em primeira pessoa - apresentaria uma visão unilateral dos acontecimentos. Ao não privilegiar nem o ponto de vista de Capitu nem o de Bentinho, entretanto, o que se estabelece é uma narrativa em que o narrador fílmico não consegue se distanciar criticamente dos fatos estatuídos pelo narrador literário, não cria uma nova visão do ocorrido (sob o ponto de vista de Capitu), nem se utiliza de forma eficaz - com todas as possibilidades que o meio lhe permite - do narrador onividente (o "olhar sem corpo") cinematográfico, o que lhe permitiria desestabilizar a posição do narrador literário. Se essa estratégia narrativa foi montada, como parece, a partir da premissa de que, em Machado, a narrativa em primeira pessoa contamina a verdade dos "fatos", pode estar aí localizada a causa da debacle da interpretação intentada pelo cineasta, já que Machado de Assis, por meio de seu narrador em primeira pessoa, não narra para elucidar um caso de adultério, mas, investindo em refletir sobre outros temas, como o ciúme ou a contradição entre aparência e realidade, o que faz é ler o mundo como paradoxo. Indecifrável, então, no contexto da representação estética, o enigma de Capitu está posto para não ser resolvido.

Como a opção dos narradores fílmicos restringe o texto a um simples relato das relações conjugais, destituindo-o das relativizações irônicas e sarcásticas do narrador autoreflexivo machadiano, é o que se pretende demonstrar.

\footnotetext{
${ }^{7}$ Cf. declaração de P.C. Saraceni em correspondência pessoal, de 10.08.92. Nessa carta, o cineasta afirma que "Lygia achava que Capitu não traiu, Paulo Emilio, que ela traiu".
} 
O ponto de vista do narrador em primeira pessoa no texto fílmico é perfeitamente factível. Seja através de um único narrador onividente, seja pela polivisão de várias "testemunhas" dos fatos, que poderiam ser narradores, por exemplo, ou personagens, também. $\mathrm{Ou}$, ainda, a narração poderia ser feita em primeira pessoa, com a voz off, através do subcódigo verbal na faixa-som. Entre inúmeros exemplos de utilização bem sucedida dessas possibilidades, recupera-se apenas três. A narrativa multifacetada de Cidadão Kane (Citizen Kane, Orson Welles, 1941), em que se busca esclarecer o enigma da vida do cidadão Charles Foster Kane pelo "depoimento" em voz off e pela presença física de vários narradores em primeira pessoa na diegese fílmica. Esse subterfúgio técnico do narrador fílmico só faz enriquecer a leitura de uma trajetória existencial, ao mesmo tempo em que dificulta uma decifração do "mistério Kane", metaforizado numa palavra - rosebud - e numa imagem - um trenó infantil entre neve e fogo. Lawrence da Arábia (Lawrence of Arabia, David Lean, 1962) segue na mesma linha narrativa, em que a "decifração" do personagem é oferecida ao leitorespectador pela interpretação polifônica de narradores diegéticos, através de sucessivos flashbacks, restando, ao final, a possibilidade do espectador montar a sua reescritura do "enigma". Finalmente, a narrativa tecnicamente brilhante de Crepúsculo dos deuses (Sunset boulevard, Billy Wilder, 1950) em que o personagem, depois de morto (circunstância narrativa que poderia ser aproximada a do narrador-defunto machadiano), em voz off, relata sua história, num longo flashback que apresenta os fatos para o espectador. Isso para não falar em experiências realizadas pelo cinema francês - Alain Resnais: Hiroshima, meu amor (1959) e Ano passado em Marienbad (1961) - em filmes que, ao problematizarem a questão do estatuto do narrador fílmico - quem narra? - ofereceram soluções inéditas e satisfatórias para esse tema vital no avanço dos processos de narração cinematográfica na contemporaneidade ${ }^{8}$.

Quer dizer, considerando as possibilidades narrativas do código fílmico, seria perfeitamente possível traduzir em roteiro cinematográfico Dom Casmurro narrado em primeira pessoa. Mas a opção de Lygia, Paulo Emilio e Saraceni não se dá na direção de

\footnotetext{
${ }^{8}$ Sobre a questão, ainda não completamente resolvida, do "narrador literário" e do "narrador fílmico", pode-se destacar dois posicionamentos teóricos relativamente recentes: cf. Genette: "Há na narração, ou ainda, atrás ou na frente dela, alguém que narra; é o narrador. Além do narrador, há alguém que escreve, e que é responsável por tudo; isto é, o autor; e isto me parece, já dizia Platão, suficiente" (GENETTE, Gerard. Nouveau discours du récit. Paris: Seuil, 1983, p.102, tradução minha). Para Albert Laffay, em Logique du cinema (Paris: Masson, 1964, p.81, tradução minha): “O narrador fílmico é aquela presença virtual escondida atrás de todos os filmes: le grand imagier". André Gaudreault, ampliando a proposta de Genette e de Laffay, em Du littéraire au filmique: système du récit (Paris: Méridiens, 1988, p.11), propõe a seguinte comparação para o estatuto dos dois narradores:

Récit scriptural: auteur (écrivain) auteur implicite, abstrait, etc. narrateur scriptural
} 
manter o ponto de vista narrativo machadiano. O que só faz diminuir a força e a complexidade do texto original: Capitu é vista por Bentinho-Dom Casmurro e toda a narrativa se faz através de um depoimento unilateral, perpassado pela problemática individualidade do personagem que narra; tudo o que sabemos é, enfim, filtrado por essa perspectiva. Ao abdicar desse enfoque, o filme encampa a possibilidade de um contador onividente (o que, também, acaba por não aproveitar), anulando, com a visada do olhar indeciso entre a aparência e a realidade, o paradoxo que dirige e coloca em impasse o discurso do narrador machadiano.

Se não há um narrador-personagem que rememora cenas do passado no tempo presente e na ação diegética - já que a utilização da voz off dos personagens Bentinho, Capitu e Ezequiel, em duas ocasiões, com veremos, pouco esclarecem sobre os fatos passados - e se os autores optaram por não usar flashbacks para atualizar essas cenas, por que não usar a narrativa cronológica, ou seja, desenvolver a história a partir de segmentos ocorridos na infância e juventude de Capitu e Bentinho, até a fase adulta de suas trajetórias? Assim, pelo menos, não teria sido necessário usar recursos como, por exemplo, o de localizar na fase adulta do casal fatos e diálogos que, no texto original, foram vividos pelos personagens adolescentes. O que acontece com os capítulos XXXII e XXXIII - no texto literário, "Olhos de ressaca" e "O penteado" - que foram fundidos na seqüência 4 (SEQ 4) do filme", em que aparece Bentinho adulto, logo após o casamento, escovando os cabelos de Capitu no quarto do casal, com visível perda da intensidade alcançada pelos fatos narrados no romance.

No texto literário, o capítulo XXXII marca o início de uma seqüência de acontecimentos capitais no desenvolvimento do romance. É nele e no seguinte que Machado de Assis introduz e constrói a poderosa metáfora dos "olhos de ressaca" que, tendo o seu desenvolvimento até o capítulo XXXVII, vai compor com os capítulos CXXIII e CXXXII onde se inclui a construção da metáfora e onde são amarradas as pontas da narrativa - uma das linhas estruturais do romance. É aí, também, que se reconhece um dos temas fundamentais da obra machadiana: o do contraste que não se resolve entre a ilusão e a realidade, na explicitação de uma poética em que o próprio texto, como reflexo do mundo, é montado como paradoxo. Essa metáfora funciona aos olhos de Bentinho - reelaborada por narrador no presente diegético - como algo a que ele não tem acesso e que o obriga ao silêncio pelo não entendimento; signo indecifrável que engolfa a própria existência da personagem e seu contexto social. Podemos constatar, então, que, ao deslocar no tempo e no

\footnotetext{
${ }^{9}$ Desse momento em diante, serão referenciadas as seqüências fílmicas (assinaladas com a abreviatura SEQ seguida pelo número seqüencial do filme) pela decupagem realizada a partir da cópia em vídeo; a numeração das seqüências, portanto, pode não coincidir com a do roteiro escrito original.
} 
espaço essas cenas cruciais na montagem do enredo literário, o texto fílmico reduz quase à nulidade a intenção de Machado de Assis. Detalhando a seqüência fílmica e comparando com as "seqüências" do romance, é possível averiguar com exatidão como isso acontece. $\mathrm{Na}$ continuidade de capítulos curtos de Dom Casmurro, o XXXII vem depois de que Bentinho "fica sabendo que amava Capitu", através da "denúncia" de José Dias. Depois, também, do capítulo em que, tendo flagrado Capitu raspando no muro a inscrição BENTO/CAPITOLINA (XIV - “A inscrição"), Bentinho, convencido de seus sentimentos, decide pedir a José Dias que interfira junto à mãe para que ela não insista com a promessa de fazê-lo padre. E que é justamente o momento em que José Dias "apresenta" a Bentinho a "definição" de Capitu que vai constituir o leitmotiv do texto, na montagem da metáfora "olhos de ressaca", fato que será decisivo na trajetória existencial de Bento Santiago. A cena ocorre precisamente quando, na expectativa da conversa de José Dias com Dona Glória, o adolescente vai ter com Capitu em sua casa. Entra na sala e a encontra, frente a um espelho, penteando-se. Ela fica sabendo que José Dias ainda não falara com Dona Glória sobre a liberação de Bentinho. Insiste com Bento: "Você teime com ele, Bentinho". Bentinho pede: "Deixe ver os olhos, Capitu". E por se lembrar da avaliação do agregado, fixa os olhos nos da menina que "traziam não sei que fluido misterioso [...] uma força que arrastava para dentro, como a vaga que se retira da praia, em dias de ressaca". Para não ser arrastado, desvia o olhar. E, por não ter o que dizer, fala que seria capaz de pentear os cabelos de Capitu. O que se sucede (Capitu sentada, Bentinho de pé, atrás da cadeira; Capitu inclinando-se para trás: olhos na boca de Bentinho e vice-versa; o beijo) e a conseqüência disto, no capítulo XXXIV ("Sou homem”), marca, sem dúvida, o ponto preciso onde começa a relação romântica, estabelecidas que estão aí as linhas estruturais da narrativa que o autor desenvolverá até o final do texto. Surpreendidos pela mãe de Capitu, os adolescentes reagem de maneira diversa: Capitu fala, disfarça, dissimulada; Bentinho cala, sem conseguir ocultar sua comoção: "Assim, apanhados pela mãe, éramos dous e contrários, ela encobrindo com a palavra o que eu publicava pelo silêncio".

A oposição palavra-silêncio vai determinar a tensão com que se confrontam os caracteres do romance daí por diante: a Capitu pública, que não teme as palavras, encobre o real, dissimulando-o em ilusão; e Bentinho-Dom Casmurro, o narrador que usa a palavra para "publicar" e, assim, entender o que acontecera na sua vida e, a partir disso, organizar sua leitura do mundo, torna público o que não diz, o que não consegue articular: isto é, o seu nãoentendimento na recuperação do vivido.

Voltemos, então, à seqüência 4 do filme, para averiguar como o cineasta constrói sua leitura para o segmento do romance que acabamos de comentar; a partir da seguinte 
decupagem:

SEQ 4: interior, dia. Quarto de Capitu e Bentinho, recém-casados. Quadro abre em plano de conjunto e câmara se aproximando do casal, que fica em plano americano, durante todo o diálogo. Capitu sentada em frente ao espelho, penteando-se. Bentinho atrás da cadeira, em pé.

B - Sabe que sou capaz de pentear o seu cabelo?

C - Você?

$\mathrm{B}$ - Eu mesmo (mexendo nos cabelos soltos de C).

C - Vai emaranhar o cabelo todo, isto sim.

$\mathrm{B}$ - Se eu embaraçar, você desembaraça depois.

C - Vamos ver esse grande cabeleireiro (C larga a cabeça par trás, olhos nos olhos de B, puxando em direção à sua: entende-se que vão se beijar).

VOZ OFF - B - Olhos de ressaca que me arrastam e me puxam para dentro de você.

A seqüência fílmica, dessa forma, desarticula completamente a arquitetura literária da metáfora machadiana. Ao deslocá-la no tempo em pelo menos cinco anos e inseri-la no espaço dos adultos casados, perde-se toda a tessitura dos temas capitais da narrativa de Dom Casmurro. Que intenção haveria, então? Como ler essa seqüência, independentemente de signos verbais que inicialmente a suportariam? Não há o referencial de que a "definição" de Capitu na metáfora "olhos de ressaca" é passada a Bentinho por José Dias, o traidor/delator de seu amor juvenil. O narrador fílmico sequer investe em metaforizar por imagens os olhos de Capitu (e haveria possibilidade mais "cinematográfica" do que essa?) ${ }^{10}$ : a câmara permanece distante da cena, sem informar mais do que o enquadramento em plano de conjunto oferece aos espectadores. Tudo fica reduzido, assim, a um quadro idílico de recém-casados no quarto de dormir. E a frase de Bentinho, em off, soa estranha à construção da cena; não há referente que a suporte nem extra-diegeticamente. Quando, na continuidade do filme, na SEQ 27, a frase retornar, em voz off de Bentinho, novamente, na cena de depois do enterro de Escobar, só servirá para alicerçar a desconfiança de Bento quanto à fidelidade de Capitu: "Olhos de ressaca, como a vaga do mar, lá fora, como se quisessem tragar também o narrador da manhã". Deslocada, ainda assim, de outro contexto literário, não correspondente à circunstância narrativa fílmica em que foi inserida.

No roteiro escrito, entretanto, Lygia e Paulo Emilio constroem essa seqüência de forma diversa, o que, embora a aproxime do texto literário, não consegue traduzir o significado essencial da cena literária. Não poderia ser diferente, afinal, pois, como já foi remarcado, a mudança de foco narrativo, praticamente anulando o ponto de vista de Dom

\footnotetext{
${ }^{10}$ A escolha da atriz (ex-modelo, mulher de Saraceni) Isabella para interpretar a Capitu cinematográfica é causa de um dos pontos mais problemáticos do filme: inexperiente, sem a physique du rôle que o papel exigia, ela não consegue desenvolver a personagem complexa - mesmo no filme - necessária à "sensação de realidade" que a narração cinematográfica pedia. E, definitivamente, não possui "olhos de cigana oblíqua e dissimulada", por mais rímel e "sombra" que a maquilagem lhe tenha imposto para as filmagens. A propósito da questão da verossimilhança física na composição de caracteres fílmicos, ver: MORIN, Edgar. As estrelas de cinema. Lisboa: Livros Horizonte, 1980.
} 
Casmurro na reconstrução dos fatos, prejudica o resgate fílmico da complexa metáfora machadiana.

Na interpretação dos adaptadores, o diálogo entre Capitu e Bentinho adolescentes se faz em off numa cena em que o adulto Bento "se inclina e prende pelas asas uma borboleta que veio pousar na janela". No diálogo que ocorre logo a seguir há, além do que foi expressado em diálogo no filme e aqui já referido, mais o seguinte:

B - aproximando-se: - Olhos de cigana oblíqua e dissimulada...

C - Isso é o que José Dias achava. E você? Quero a sua opinião!

B - Acho que são olhos de mar de ressaca... Aquele mar que vem e me arrasta e me puxa para dentro de você.

Logo após, o roteiro indica que deve ser filmado um demorado beijo, enquanto a câmara (foco do narrador) se afasta e enquadra o céu e vozes infantis em off conversam: é o diálogo pinçado do capítulo XLIX ("O primeiro filho”) em que Capitu apresenta a Bentinho a opção "Capitu ou Dona Glória”. A utilização desse diálogo aqui não persegue a intenção machadiana de mostrar mais uma vez que Bento, face à dissimulação de Capitu, não consegue articular palavra: "Era tão estranho tudo aquilo, que não achei resposta". A cena fica diluída nas recordações de Bentinho adulto, quando relembra seus diálogos juvenis, sem conseguir juntar as identidades das duas atitudes de Capitu, numa e noutra cena, remarcadas pelo signo da dissimulação e da palavra desenvolta, fácil e que encobre intenções. Quer dizer, ficam esvaziados de sentido os índices da oposição que se estabelece entre os caracteres e que dominará as relações entre o casal: "dous e contrários”, a palavra e o silêncio. Na passagem do roteiro escrito para o making fílmico, com o não aproveitamento do diálogo sobre José Dias e a introdução da metáfora olhos de ressaca - com todas as conseqüências que o fato traz -, a adaptação resta absolutamente redutora. Dessa forma, o texto fílmico limita-se a codificar devaneios rememorativos de um jovem casal em idílio amoroso, distanciando-se das dubiedades e ambivalências possibilitadas pelas palavras no romance.

Quando se verifica isso, a interpretação do filme - considerado junto com o roteiro escrito -, enquanto projeto de recriação num outro código do texto literário, mesmo se levarmos em conta a intenção explícita dos autores de investir numa "narrativa sobre Capitu", e não do ponto de vista de Dom Casmurro, só pode restringir-se à perseguição de trilhas que, truncadas, interrompidas, não aproveitadas, levam à produção de uma narrativa fílmica definitivamente distanciada da narrativa literária e, conseqüentemente, da intenção estética e do projeto machadiano. Resta verificar, então, se o que se constrói aí tem a consistência estética de uma tradução criativa. 
Traduzir, mesmo de um código estético para outro, sob o "signo da invenção", sem perda do sentido essencial, é possibilidade que Haroldo de Campos já assinalara ser prática plenamente factível ${ }^{11}$. Isso acontece quando não é traduzido apenas o significado, mas o signo na sua materialidade, ocorrendo o avesso da tradução literal, na postura inventiva do tradutor. Sob esse ponto de vista, a invenção resultaria como sendo ampliação do significado original. "Olhos de ressaca" é signo verbal cuja materialidade, no entanto, não se amplia pela "invenção" dos tradutores fílmicos, no caso de Capitu.

Roteiristas e diretor, na construção de sua tradução fílmica da narrativa de Dom Casmurro, inventam cenas cinematográficas que resultam inúteis para a iluminação do significado essencial da história primeira. É o caso dos retornos fílmicos do "penteado" e dos "olhos de ressaca", comentados a seguir.

Tanto no roteiro escrito de Capitu (SEQ 12 e 13, p.59-65) como no filme (SEQ 9 e 10), narra-se a ida de Capitu e Bentinho a um baile e a revelação pela mulher de que estava esperando um filho. A SEQ 8 - do baile - é tradução do capítulo CV (“Os braços”). As de número 9 e 10 resultam de invenção tradutora e buscam recriar em imagens algumas intenções literárias. Vejamos como isso acontece e até que ponto os roteiristas e diretor conseguem seu intento.

A sucessão dos capítulos iniciada com "Os braços" e que contém CVI ("Dez libras estrelinas") e CVII ("Ciúmes do mar") serve ao narrador para remarcar o tema do ciúme, já apresentado e desenvolvido em outros pontos da narrativa, e precede, imediatamente, o capítulo "Um filho" (CVIII), onde se narra ("Escusai minúcias") o nascimento de Ezequiel. Ao seqüenciar fatos que revelam in crescendo o ciúme de Bentinho, imediatamente antes da "vertigem e da loucura" que foi para ele o nascimento do filho, o narrador elabora como que uma etapa do desenvolvimento do processo de ciúme apanhada em seu limite. O nascimento da criança interrompe, por assim dizer, a continuidade narrativa, a qual, nos capítulos seguintes (a partir de "As imitações de Ezequiel”), retomará o curso até os fatos da morte de Escobar, da tentativa de infanticídio e da separação de Bento da mulher e do filho.

A seqüência do baile é tradução inventiva da cena literária. Por se tratar de uma possibilidade que renderia em ação fílmica, há evidente alargamento da duração dos fatos nas imagens do filme. Os adaptadores não desperdiçariam - num texto tão carente de "ação" - a

\footnotetext{
${ }^{11}$ Cf. Campos: "Quando não se traduz apenas o significado, mas o próprio signo na sua materialidade, dá-se o avesso da tradução literal (mesmo em tradução intersemiótica), resultando a tradução criativa" (CAMPOS, Haroldo de. A poética da tradução. A arte no horizonte do provável. São Paulo: Perspectiva, 1969, p.98). A idéia de que o tradutor intersemiótico precisa "inventar" também é presente em SOURIAU, Etiènne. "Ser-lhe-á necessário inventar certas coisas, esquecer outras, portanto repensar artisticamente esse universo, de acordo com suas próprias normas". In: Correspondência das artes. São Paulo: Cultrix, 1983, p.266.
} 
possibilidade de "fazer cinema" (utilização de plano geral, panorâmica, travelling e panotravelling, numa montagem que, com cortes pouco profundos no tempo e no espaço, rápidos, "enche" os olhos do espectador) na cena do baile em que Capitu dança com os braços nus sob os olhos de um ciumento Bento Santiago.

Pode-se afirmar que, do ponto de vista da tentativa de tradução fílmica, essa é, sem dúvida, uma das sequiências mais bem sucedidas. Não só pelo que de ação especificamente cinematográfica ela constrói, mas porque consegue transcriar em imagens em movimento a intenção do narrador literário, sem perda do significado essencial e até ampliando a cadeia dos significados "olhar de Bento em Capitu-ciúme-impotência de Bento em verbalizar suas emoções-agilidade e desenvoltura de Capitu em dissimular".

Isso acontece porque, no filme, articulam-se duas seqüências - 9 e 10 - que não traduzem índices literários: produto da invenção dos roteiristas, depois do baile em que Capitu dança de braços desnudos, segue-se a volta para casa com cenas no tílburi e no quarto do casal. Um Bentinho amuado que não fala durante todo o trajeto e que, na intimidade da alcova, desabafa: "Quero que saiba que me desagradou profundamente vê-la com os braços despidos, passando de mão em mão". Capitu sente que o marido está de mau humor e age para dominar a situação. Assim se indica no roteiro a descrição do que deve ser filmado:

De repente, levanta-se, vai até o canapé e ali senta-se ao lado de Bentinho, ficando de costas para ele e inclinando a cabeça para o peito:

C - Quer me ajudar aí atrás, querido? Indica-lhe com a escova a abertura do corpete. Não acerto com os colchetes, há de ver que engordei. [...]

Inclina para trás a cabeça, acomodando-se nos joelhos dele. Estende-lhe molemente a escova.

C - Quer me ajudar a desembaraçar o cabelo?

Ele apanha a escova. Chega a começar a escovar-lhe a cabeleira e pára de repente. Desvia de novo para o chão o olhar sombrio.

B - Não sei desembaraçar cabelos. [...]

C - Sabe, sim, como é que não sabe? Está esquecido de que um dia chegou até a fazer as minhas tranças?

B - (seco) Era diferente, Capitu [...].

C - Você se aborreceu, querido. E logo hoje...

B - Logo hoje, por quê?

$\mathrm{C}$ - Porque justamente hoje eu tinha resolvido lhe contar... [...] Vamos ter um filho. [...]

B - Vamos o quê?!

C - Vamos ter um filho. [...]

Bentinho tomba de joelhos ao pé da mulher. Toma-a pela cintura e esconde a face no seu peito. Ela acaricia-lhe os cabelos, afetuosa e maternal. Aperta um pouco os olhos. (p.65-67)

Na construção dessa seqüência, os roteiristas e o diretor do filme buscaram resgatar a circunstância de sedução de Bentinho por uma Capitu que sabe como lidar com as emoções do marido. O segmento, no filme, acaba sendo filmado com algumas modificações: Bentinho está recostado na cama, não num canapé, não chega a desabotoar o vestido nem a pentear o cabelo da Capitu. Mas, substancialmente, o sentido é o mesmo indicado no roteiro escrito. 
Pinçou-se da SEQ 4, já comentada, a situação de Capitu oferecer seus cabelos para que Bentinho os manipulasse, numa evidente busca de clima de sedução em que a mulher detém a iniciativa e domina a situação. O retorno da atitude feminina aqui não funciona na mesma direção e Capitu se vê compelida a revelar a gravidez num momento em que não há a ambiência emocional ideal para isso. Quer dizer, existe continuidade da idéia desenvolvida na sequiência fílmica do "penteado" e que se distancia ainda mais dos signos literários do capítulo XXXIII com a montagem da oposição palavra-silêncio, "dous e contrários", linhas estruturais da narrativa machadiana e que sustentariam a trama literária.

Com relação ao retorno, na continuidade da narrativa fílmica, do tema dos "olhos de ressaca", o fato se dá não como ampliador do significado literário, como já foi remarcado, mas como confirmação da leitura redutora efetuada pelos autores cinematográficos. Vejamos, no roteiro escrito:

SEQ 30 - Exterior, dia. No tílburi. Bentinho e José Dias voltam ao cemitério. [...]

$\mathrm{B}$ - (a bater o castão da bengala no teto do tílburi e dirigindo-se ao cocheiro) Por favor, quer parar um instante? (volta-se para José Dias) Vai indo, por favor, vai que logo nos encontramos em casa. JD - (surpreso) Mas Bentinho...

B - (abrindo a porta do carro) Quero andar um pouco, é isso. Não demoro. Até já. [...]" (p.143147).

Na continuidade, a seqüência articulada no roteiro mostra Bentinho caminhando pela rua até que, numa viela, ouve os sons românticos de uma rabeca, vibrando os sons da canção napolitana: "Vede il mare quanto è bello...".

No filme, essa seqüência inicia conforme o roteiro escrito. Mas há uma mudança importante ocorrida com inserção da fala de Bentinho, em off. Assim:

SEQ 26 - Exterior, dia. Plano de conjunto, travelling lateral. Bento e José Dias voltam em carro aberto. B não fala, taciturno, como que a remoer idéias. Pede para parar o tílburi e desce. JD segue só. B segue caminhando, plano de conjunto, ruelas escuras, vazias. Close em B.

VOZ OFF (B): "Olhos de ressaca, como a vaga do mar, lá fora, como se quisesse tragar também o nadador da manhã". Plano de conjunto, B caminha, rua deserta. Numa esquina um homem toca violino: "Vede il mare quanto è bello". CORTE.

Considerando o acréscimo da fala em off, o que se constata é que houve a intenção de reunir ao conteúdo do capítulo CXXIII ("Olhos de ressaca”, p.272), o CXXVI ("Cismado", p.276) e o CXXVII ("O barbeiro", p.278). Ou seja, depois do enterro de Escobar, e tendo sido narrado, antes, na SEQ 25, o momento em que Bento olha Capitu olhando o defunto, é que retorna na diegese a metáfora "olhos de ressaca". Deslocada do seu contexto literário (capítulo CXXIII) - que, como já vimos, é o ponto onde se amarram as pontas da narrativa, com a conclusão da metáfora complexa e tema fulcral do romance -, a construção machadiana 
perde seu significado emblemático, em detrimento de um arranjo de imagens e palavras que busca tão somente atualizar para o espectador que "os olhos de ressaca que seduziram Bento, também engolfaram Escobar". E é disso que o narrador cinematográfico pretende que o espectador se dê conta. Dessa forma, o retorno da expressão "olhos de ressaca" ao contexto do filme, mesmo considerando-se a invenção de introduzir a frase musical do violinista que enriquece a leitura do signo "mar”, não aproxima a transcriação fílmica da intenção literária.

Assim, como já foi evidenciado na análise comparativa de outras seqüências fílmicas com cenas e capítulos do original literário, mediada pelo roteiro escrito, e levando-se em conta as possibilidades narrativas dos dois códigos autônomos, os autores cinematográficos, aqui considerados como sendo os roteiristas e o cineasta, ao mesmo tempo em que não conseguem transcriar na sua essência o significado do texto literário, também não criam uma obra em si mesma, independente do texto primeiro, a qual, problematizando questões alçadas do romance, fizesse avançar o sentido do hipotexto.

Não é necessário comparar o roteiro escrito na sua totalidade e a decupagem de todo o filme com o texto literário para concluir que Dom Casmurro, em sua passagem para Capitu, transforma-se numa narrativa afirmativa, diante da qual ninguém fica com nenhuma dúvida: Capitu é adúltera; Bentinho é um tolo; Escobar, um fantasma que nada; José Dias uma sombra superlativa, a caricatura de si mesmo. Pelas seqüências e cenas selecionadas para a comparação, percebe-se que o romance de impressões, de sutilezas e dubiedades resultou em uma obra que não evolui, nem dramática nem narrativamente: redução fílmica para um texto literário de arquitetura requintada. É verdade, também, constata-se, que o roteiro escrito aproxima-se mais da proposta estética de Machado do que o resultado fílmico. Para se escrever um roteiro funcional é preciso que se articule idéias narrativas eficazes. As palavras importam menos e têm sua força expressiva apenas nos diálogos. A chave seria a ação, portanto. O roteiro de Lygia e Paulo Emílio, destinado a contar a história de Dom Casmurro sob o ponto de vista de um narrador em terceira pessoa, mas não onividente (ou seja, sem incluir outros pontos de vista, como o de Capitu, por exemplo), remarca o ponto de vista de Dom Casmurro sem, no entanto, assumir a complexa estrutura narrativa do personagemnarrador literário. Com isso, destrói-se a armação eficaz e absolutamente perfeita do texto literário, sem que seja traduzida numa narrativa fílmica eficaz para narrar a história de Capitu.

Considerando alguns fatos sobre a gênese da proposta do cineasta e sobre a postura dos tradutores fílmicos, é possível, no entanto, entender alguns dos mecanismos que conduziram à empreitada redutora.

Já foi referido que o ponto crucial do fracasso estaria na mudança do ponto de vista do 
narrador literário em sua passagem para o cinema. É fundamental para o romance de Machado de Assis que o narrador seja o personagem que narra em primeira pessoa: as invenções fílmicas da adaptação do romance não se mostraram suficientes para suprir a ausência do ponto de vista de Dom Casmurro-Bento Santiago-Bentinho.

Paulo Cezar Saraceni, ao encomendar um roteiro para um "filme sobre Capitu e não Dom Casmurro" "12, já estabelece os limites do problema, isto é, importa a personagem Capitu e não Bentinho para a narrativa que quer contar com imagens. No esforço de conseguir essa visada, os roteiristas acabam não concretizando nem o perfil da personagem feminina, determinando a direção do olhar narrativo, nem constroem um Dom Casmurro com a sutileza, a ambigüidade e as contradições do personagem literário. Algumas outras circunstâncias do processo de criação certamente contribuíram para isso, como veremos.

São reveladores alguns fatos precedentes: Paulo Emilio já se manifestara pela "culpa" de Capitu ao classificar a personagem do filme de Saraceni - Porto das caixas - como uma "fascinante e atroz Capitu suburbana"13 (aquela triste criatura que, com o auxílio do amante, mata o marido, no filme de 1962). Paulo Cezar revela também que, ao interpretar o romance de Machado para realizar a tradução do livro ao filme, Salles Gomes já se posicionara sobre a questão: “[...] foi complicado na época convencer Paulo Emilio e Lygia de que o filme era sobre Capitu e não Dom Casmurro [...], Paulo Emilio dizendo que Capitu traiu" "14. Ainda, se analisarmos fatos posteriores ao filme, na trajetória criadora do ficcionista Paulo Emilio, é possível detectar indícios que explicariam a posição assumida por ele na ocasião da montagem do roteiro. Em seu único texto de ficção (1977), Três mulheres de três PPPês, no qual três contos longos fixam perfis femininos, há um - "PI: duas vezes com Helena" - em que a personagem, Helena, trai o marido para ter um filho do amante. Texto que, aliás, o cineasta Saraceni transformaria em filme sob o título Ao sul do meu corpo (1981), depois de ter novamente filmado um texto de Lucio Cardoso (Crônica da casa assassinada) que se estrutura em torno de uma forte figura de mulher (Nina, que, supostamente, teria traído o marido e tido um filho com o amante).

\footnotetext{
${ }^{12}$ Cf. correspondência pessoal do diretor, de 10.08.92, em que ele afirma: "Posso lhe garantir que desde que li Dom Casmurro, aos 17 anos, me apaixonei por Capitu. Mais tarde, em 1966, sofri a síndrome de Bentinho: um ciúme devastador, misturado com perseguições políticas, censura ao meu filme de 1965 - O desafio. O filme surgiu para mim como uma iluminação para o que eu estava passando".

${ }^{13}$ Idem.

${ }^{14}$ Cf. TELLES, Lygia Fagundes, op.cit. p.6: “[...] eu já fizera até algumas anotações para o romance As meninas". Só que Lygia afirma que isso aconteceu em 1969: um evidente engano, já que o filme é de 1968; no mínimo, os fatos narrados pela autora em "Às vezes, novembro", paratexto no livro em que publica o roteiro de Capitu, aconteceram em 1967.
} 
Os acontecimentos arrolados não devem ser considerados, entretanto, como "prova" da postura de Paulo Emilio - mesmo porque o que fundamentalmente importa na análise da interpretação efetuada na tradução fílmica é a relação entre o romance e o filme - mas apenas como fatos que podem auxiliar na compreensão de como se cristalizou essa interpretação no imaginário do cineasta e dos roteiristas.

Da mesma forma, considerando a trajetória criadora da escritora Lygia Fagundes Telles, é possível compreender sua indecisão ao interpretar o texto literário: na época, certamente, já estruturava as personagens femininas que vestiria como As meninas, seu romance a ser lançado em 1973; ou as que povoam os contos de Antes do baile verde (1972). Nos quais pode-se dizer, sem dúvida, que está presente um dos temas obsessivos da autora - a infidelidade: "não a infidelidade imediata e grosseira das tramas folhetinescas, mas a do desencontro", momentos em que Lygia assume, como narradora, o "ponto de vista lírico do traído" (OSCAR apud MEDINA, 1985, p.60). Parece evidente que na construção de sua Capitu fílmica - juntamente com o marido Paulo Emilio - esse ponto de vista deve ter influenciado. Não poderia ser diferente: toda tradução implica interpretação. E tanto Paulo Emilio como Lygia - e, mais do que os dois, Saraceni, o diretor e autor fílmico - investiram em interpretar o "enigma Capitu", limpando o texto literário de suas necessárias ambigüidades, para tentar "explicar" Capitu. Por meio dessa decisão autoral, a incontornável narrativa de Bentinho-Bento Santiago-Dom Casmurro, construída na primeira pessoa literária, é articulada por um narrador fílmico em terceira pessoa, distanciado, correspondendo ao que Gaudreault chama de le grand imagier (1988, p.11), o qual é o montador, plano a plano imagético, da narrativa cinematográfica. Nessa operação, perde-se o essencial da elaborada tessitura literária, já que, tal como está construído no romance, é no narrador problemático de Machado que se deve buscar a chave para o entendimento da Capitolina-Capitu literária.

O que resulta, como vimos, é uma tradução que, ao reduzir a rede intrincada das impressões do narrador literário - construída numa linguagem de sofisticadas sutilezas e dubiedades - a uma narração em terceira pessoa, opera de forma absolutamente afirmativa. Um filme em que a trama não evolui: fica parada, dando voltas sobre si mesma, presa às evidências da imagem: o "eis aqui" presentificador que caracteriza os fotogramas fílmicos.

A constatação desse fato, entretanto, não poderia levar à conclusão de que Capitu é produto fílmico equivocado porque tradução intersemiótica equivocada de Dom Casmurro. Permanece o pressuposto de que cada um dos três textos - considerados em sua especificidade - são obras distintas em suas características formais: uma, o livro - narrativa literária; outra, o filme - narrativa cinematográfica; e ainda outra, o roteiro escrito, o qual, 
inclusive, pode ser lido, hoje, tanto quanto o romance e o filme, de forma independente. A análise comparativa dessas três textualidades - roteiro escrito, filme e roteiro - visou exclusivamente a verificar como, ao realizar tal operação transtextual, os autores fílmicos interpretaram Dom Casmurro. Da mesma forma como, sob a ótica das linhas interpretativas aqui trazidas para ler o romance, a produção desse sentido se mostra questionável, eis que se articula como tradução redutora do projeto literário de Machado de Assis e se constitui como interpretação que não alcança e muito menos supera as intrincadas implicações narrativas machadianas, como se evidenciou neste ensaio. Constata-se, nesse contexto, que "le grand imagier" articulado por Saraceni para criar a sua história de Capitu caiu na cilada armada por Machado, eis que "o livro tem algo de armadilha, com lição crítica incisiva" (SCHWARZ, 1997, p.9). Dessa forma, no âmbito de seu admitido projeto fílmico de narrar um filme "sobre Capitu”, o cineasta, ao descartar as incongruências do narrador literário, anula a sofisticada armação montada por meio daquilo que Roberto Schwarz identifica como "ênfases desconcertantes, que vão formando um enigma" (1997, p.9).

Conclui-se, dessa forma, que o filme, considerado na sua especificidade estética, é projeto transcriativo fracassado não somente pelas razões até aqui alinhadas, mas porque, ao partir do explicitado projeto de levar Dom Casmurro ao cinema, Capitu não resultar nem uma tradução criativa e convincente do romance, nem uma obra que, por meio de invenções formais e conteudísticas, faça avançar o sentido do hipotexto. O principal motivo para isso seria o fato de que, ao descartar a complexidade formal do romance, afastando o foco de um narrador não confiável e naturalmente suspeito, a narrativa fílmica não articula, ainda que em condição de intertexto, a correspondente criação da ambigüidade obscura alcançada pelo narrador literário em primeira pessoa, condição mesma da singularidade formal da obra de Machado de Assis.

\section{Referências}

ASSIS, Machado de. Dom Casmurro. In: Obra completa. (COUTINHO, Afrânio. (org.)) v.1. Rio de Janeiro: Editora Nova Aguilar, 1986.

CAMPOS, Haroldo de. A arte no horizonte do provável. São Paulo: Perspectiva, 1969.

GAUDREAULT, André. Du littéraire au filmique: système du récit. Paris: Méridiens, 1988.

GENETTE, Gérard. Palimpsestes. Paris: Seuil, 1982. 
GENETTE, Gérard. Nouveau discours du récit. Paris: Seuil, 1983.

GOMES, Paulo Emilio Salles. Crítica de cinema no Suplemento Literário. v.2. Rio de Janeiro: Paz e Terra, 1981.

LAFFAY, Albert. Logique du cinéma. Paris: Masson, 1964.

MEDINA, Cremilda de Araújo. A posse da terra: escritor brasileiro hoje. São Paulo: Imprensa Nacional - SESC - SP, 1985.

MELLO E SOUZA, Cláudio. Guia de Filmes. v.16, Jul.-Ago. Rio de Janeiro: INC, 1986.

METZ, Christian. A significação no cinema. São Paulo: Perspectiva, 1972.

MIMOSO-RUIZ, Duarte. Narração fílmica e narração literária: perspectivas semiológicas. Anais do $1^{\circ}$ Congresso Abralic, Porto Alegre, v.1, 1989.

MIRANDA, Luiz A. F. Dicionário de cineastas brasileiros. São Paulo: Art, 1990.

MORIN, Edgar. As estrelas de cinema. Lisboa: Afrontamento, 1980.

PLAZA, Julio. Tradução intersemiótica. São Paulo: Perspectiva, 1987.

SCHWARZ, Roberto. A poesia envenenada de Dom Casmurro: Duas meninas. São Paulo; Companhia das Letras, 1997.

SOURIAU, Étienne. A correspondência das artes: elementos de estética comparada. São Paulo: Cultrix, 1983.

TELLES, Lygia Fagundes; GOMES, Paulo Emilio Salles. Capitu. São Paulo: Siciliano, 1993. 